\title{
Community Response of Cladocera to Trophic Stress by Biomanipulation in a Shallow Oxbow Lake
}

\author{
Csaba Berta ${ }^{1}$, Béla Tóthmérész ${ }^{2, *}$, Marta Wojewódka ${ }^{3}$, Olga Augustyniuk ${ }^{3}$, János Korponai ${ }^{4,5}(\mathbb{0}$, \\ Boglárka Bertalan-Balázs ${ }^{6}$, Alex Sándor Nagy ${ }^{1}$, István Grigorszky ${ }^{1}$ and István Gyulai ${ }^{1}$ \\ 1 Department of Hydrobiology, University of Debrecen, Egyetem tér 1, H-4032 Debrecen, Hungary; \\ csaba.berta91@gmail.com or berta.csaba@science.unideb.hu (C.B.); \\ nagy.sandor.alex@science.unideb.hu (A.S.N.); grigorszky.istvan@science.unideb.hu (I.G.); \\ istvan.gyulai@gmail.com (I.G.) \\ 2 MTA-DE Biodiversity and Ecosystem Services Research Group, Egyetem tér 1, H-4032 Debrecen, Hungary \\ 3 Research Centre in Warsaw, Institute of Geological Sciences, Polish Academy of Sciences, Twarda 51/55, \\ PL00818 Warsaw, Poland; wojewodkamarta@gmail.com (M.W.); aug.olga@gmail.com (O.A.) \\ 4 MTA-PE Limnoecology Research Group, Wartha Vince u. 1, H-8200 Veszprém, Hungary; \\ korponai.janos@iif.hu \\ 5 Department of Environmental Sciences, Sapientia Hungarian University of Transylvania, Calea Turzii str. 4, \\ 400193 Cluj-Napoca, Romania \\ 6 Department of Physical Geography and Geoinformatics, University of Debrecen, Egyetem tér 1, \\ H-4032 Debrecen, Hungary; geogis.bb@gmail.com \\ * Correspondence: tothmerb@gmail.com or tothmeresz.bela@science.unideb.hu
}

Received: 26 February 2019; Accepted: 12 April 2019; Published: 1 May 2019

\begin{abstract}
Studying contemporary and subfossil Cladocera (Crustacea) communities, we explored the effect of top-down stressors on the cladoceran communities; we are also interested in the coherence of the contemporary and subfossil communities. The studied Cibakháza oxbow lake is in E Hungary, on the left-floodplain of the River Tisza; it is a large, long, and shallow oxbow lake. Three areas of the oxbow lake were distinguished based on the strength of top-down stress: protected area with low top-down stress, biomanipulated area with high top-down stress, and recreational area with moderate top-down stress. Altogether, we identified 28 taxa in the contemporary and subfossil communities in the oxbow lake. We found that the species number of the contemporary Cladocera communities was lower (protected area: 13; biomanipulated area: 9, and recreational area: 14) than in the subfossil communities (protected area: 20; biomanipulated area: 16, and recreational area: 14). Among the environmental variables, we observed differences between the protected and biomanipulated area, while the recreational area showed a transition. Species number, abundances, and Simpson diversity also showed the effect of the fish introduction. There were no differences in beta-diversity among the contemporary and subfossil Cladocera community. The non-metric multidimensional scaling (NMDS) ordination showed that the biomanipulated area in the case of the contemporary communities was separated from the other areas, while in the case of the subfossil communities, there was no separation according to top-down stress. Our results showed that the number of species of contemporary Cladocera communities was lower in each area (3-10;3-9; 5-9) compared to the subfossil communities $(6-17 ; 7-12 ; 8-12)$. However, the highest abundances were found in the biomanipulated area due to the appearance of small-sized Cladocera species. Our findings suggest that the effect of a short-time fish introduction is restorable when the oxbow lake has a protected part.
\end{abstract}

Keywords: zooplankton; diversity; biomanipulation; nature protection; anthropogenic impacts; restoration 


\section{Introduction}

Over the whole world, many aquatic ecosystems have been affected by significant transformation. Numerous studies highlight the disturbance of freshwater systems as the effect of natural and anthropogenic pressure. Disturbance or human utilization of these ecosystems is a cause of general anxiety due to their importance in providing ecosystem services [1]. Shallow lakes can be regarded as biodiversity hotspots [2] in the context of the global prevalence of water insecurity [3]. In the last decades, numerous research works have focused on zooplankton dynamics in freshwater and marine ecosystems [4], emphasizing the importance of zooplankton species in the maintenance of food webs [5], serving as a food source for different aquatic animals [6]. These oxbow lakes are endowed with many ecosystem services and have a substantial impact on the ecology, biodiversity, and social-economy of the surrounding localities, which makes them a priority for research and conservation $[7,8]$. These environments are ecotones between lotic [9] and lentic [10] and have regular lateral water connectivity to the main river. This connection to the river distinctively supports a high diversity of habitats for both flora and fauna [11,12]. What is more, oxbow lakes create a multiplicity of habitats and feeding grounds for various organisms such as birds, fishes, amphibians, macroinvertebrates, phytoplankton, and zooplankton $[13,14]$.

Cladocera is one of the most important component of microcrustacean zooplankton. Moreover, they are sensitive indicators of environmental changes [15]. They usually indicate early signals of ongoing changes because of their prompt response to environmental changes. These changes seem to be intensified in small waterbodies such as ponds and oxbow lakes due to their small area and low water volume. Hence, oxbow lakes are especially vulnerable to climate change and habitat degradation.

Cladocera play an essential role in freshwater systems since they are in a middle position in the freshwater trophic structure. The Cladocera community structure is highly determined by the food web structure and not greatly determined by hydrological factors [16] compared to other organism groups such as macroinvertebrates [17] and fishes [18], especially in such peculiar ecosystems as oxbow lakes.

Generally, the stressor factors of aquatic ecosystems can be divided into biotic and abiotic ones. Nutrient enrichment (eutrophication) in lakes increases the number of levels of trophic structures and also increases the zooplankton biomass [19-21]. However, low structured food webs can be found under the highest eutrophic conditions. In addition to nutrient supply, predators also effect zooplankton. For instance, size-selective feeding of planktivorous fishes has a great impact on the dynamics and structure of the zooplankton community in temperate lakes [22-24]. High pressure from predation leads to decreases in zooplankton abundances [25]; small-sized species appear; and the size of already existing individuals of the present community also declines [26,27]. Besides the feeding type composition of the fish community, juveniles have a greater effect on the zooplankton community, since all freshwater fish feed on zooplankton during the young of the year stage [27]. In extreme situations, the predation may cause the disappearance of the prey population [28]. In the case of Cladocera, the contribution of small taxa (e.g., Bosmina longirostris) increases [29] due to the top-down regulation of fish [30,31].

All in all, multiple environmental stressors influence the zooplankton community. Their effects usually overlap, and very often, it is impossible to deduce which biocenotic changes were triggered by a given a factor. To track the spatial distribution of Cladocera communities under a range of pressures in small aquatic ecosystems, an oxbow lake in Hungary was studied. The Cibakháza oxbow lake is on the left-bank floodplain of the River Tisza, in East Hungary. It is one of the largest oxbow lakes in Hungary ( $16.2 \mathrm{~km}$ long) and was created by the straightening of the meander.

We analyzed the contemporary and subfossil Cladocera communities and their abiotic environmental parameters. In the present study, three main hypotheses were assumed:

(1) The separate analyses of the contemporary and subfossil Cladocera communities are not representative enough to specify the whole of the Cladocera communities. 
(2) Due to intensive fish introduction, the structure and quantitative relationship of the Cladocera community change in the biomanipulated area.

(3) Due to the accumulation capacity of sediment, we may find more species in the subfossil community than in the contemporary community.

\section{Materials and Methods}

The studied oxbow lake is in East Hungary (Figure 1) on the left-bank floodplain of the River Tisza (latitude N $46^{\circ} 57^{\prime} 36.21^{\prime \prime}$, longitude E $\left.20^{\circ} 11^{\prime} 16.23^{\prime \prime}\right)$. It has a surface area of $1.4 \mathrm{~km}^{2}\left(\mathrm{~A}=1.4 \mathrm{~km}^{2}\right)$ with a maximum depth of $6.22 \mathrm{~m}\left(\mathrm{~d}_{\max }=622 \mathrm{~cm}\right)$ and an average depth of $2.65 \mathrm{~m}$.

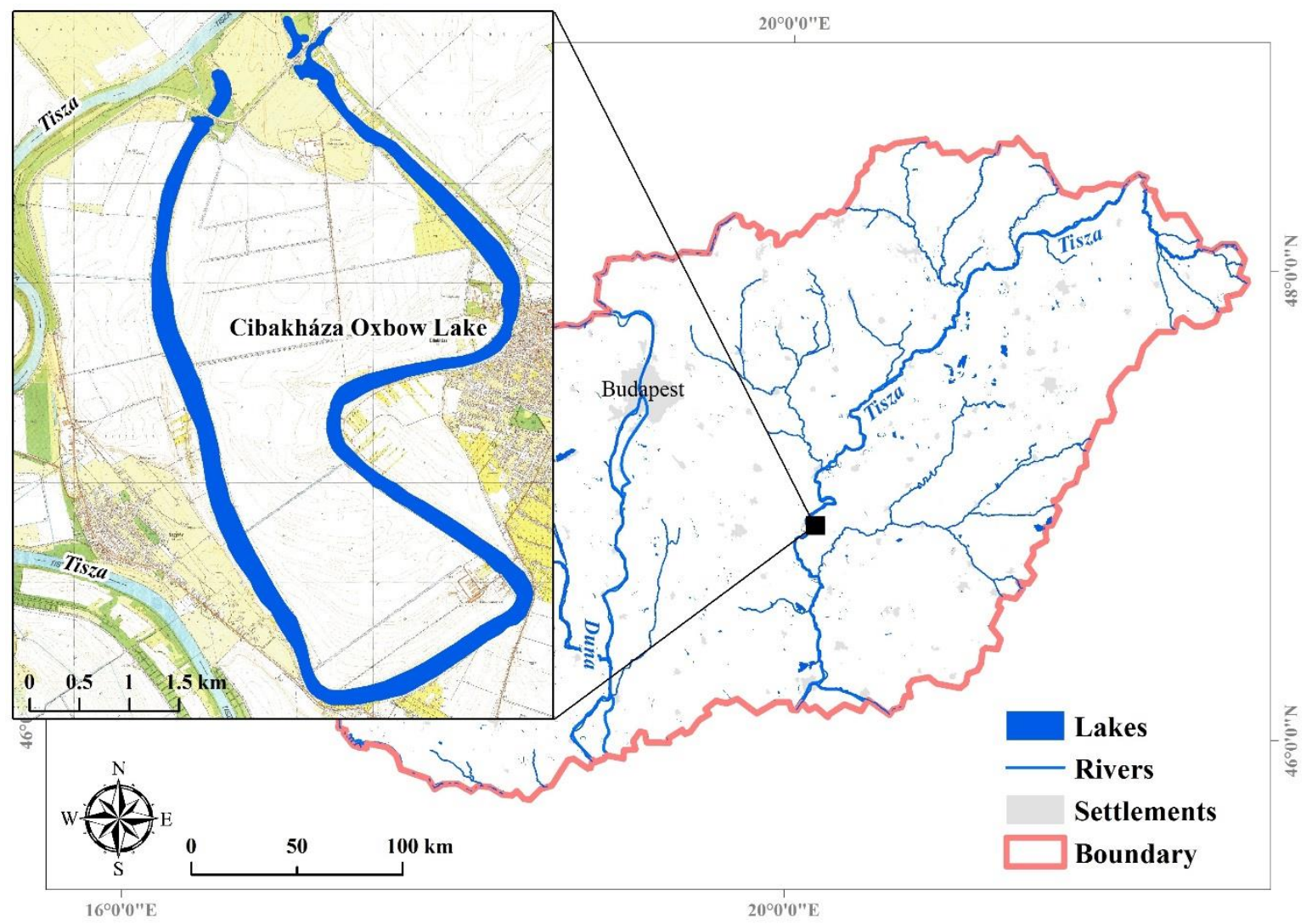

Figure 1. Location of the studied oxbow lake with the markings of lakes, rivers, settlements, and the border of Hungary.

The oxbow lake was divided into three separate areas to explore the effect of biomanipulation (Figure S1). These areas are separated from each other by embankments, with small channels that allow the water to flow through to each area. The protected area of the oxbow lake was created as a nature conservation area for birds and mammals and in this study was treated as the reference area for Cladocera communities. The biomanipulated area was adopted for angling with intensive fish introduction. This area is separated by $5 \times 5 \mathrm{~cm}$ plastic nets from the other two areas to prevent the migration of fish. They are fixed by wire to the bottom. The recreational area is used for recreation purposes, but there has been no fish introduction and/or other kinds of management to create a transition area next to the protected and biomanipulated areas.

There was a fish introduction into the biomanipulated area in spring of $4000 \mathrm{~kg}$ of juvenile carp; approximately $0.02 \mathrm{~kg} /$ individual and 10,000 juvenile pike. Most of the juvenile carp became prey for Copepods [32] and for the pike [33], which were introduced into the biomanipulated area at the same time. The remainder of the carp had size-selective feeding habits and mainly fed on small rotifers [32]. Simultaneously, a small-sized species of common carp (Cyprinus carpio) 
( 0.1-0.12 kg/individual) was also introduced. However, they were eaten by larger predators within a short period [34]. Based on this information and the feeding strategies of fish, the $2550 \mathrm{~kg}$ of common carp (C. carpio) (1.5-2 kg/individual)—which were also introduced into the biomanipulated area at the same time-probably put predation pressure on the Cladocera community [35] in this part of the oxbow lake.

There were fifteen sampling sites; samples were collected during the summer period. Seven sites were in the protected area. Five sampling points were chosen from the biomanipulated area and three from the recreational areas. At each site, first the open water and submerged coverage were registered, by our own observation. Next, the plankton samples were collected using a Schindler-Patalas plankton trap [36] with a 35- $\mu \mathrm{m}$ mesh, to follow the contemporary Cladocera community. The basic variables of the oxbow lake were also measured. For this purpose, an YSI EXO2 (Yellow Springs Instrument Company, Yellow Springs, USA) (Xylem, 599502-01) multiparameter probe was used, and the following parameters were determined: water temperature, dissolved oxygen concentration, conductivity, and $\mathrm{pH}$. The next steps included sediment and water sampling. Sediment samples were taken using a gravity-corer (Jackson, USA) (WaterMark ${ }^{\circledR}$, diameter of $0.06 \mathrm{~m}$ ) [37]. The topmost $1 \mathrm{~cm}$ of soft sediment was used for further investigation of subfossil Cladocera.

The laboratory measurements of water samples included chlorophyll-a content, suspended solids, $\mathrm{PO}_{4}$, and dissolved inorganic nitrogen analysis. The chlorophyll-a was analyzed based on the EPA Method 445.0: in vitro determination of chlorophyll-a and pheophytin a in marine and freshwater algae by fluorescence. The $\mathrm{PO}_{4}$ was analyzed based on the EPA Method 365.3: phosphorous, all forms (colorimetric, ascorbic acid, two reagent). Suspended solids were analyzed based on the EPA Method 160.2 (gravimetric dried at $103-105^{\circ} \mathrm{C}$ ). Dissolved inorganic nitrogen was analyzed based on the EPA Method 1687 (total Kjeldahl nitrogen in water and biosolids by automated colorimetry with preliminary distillation/digestion).

The laboratory measurements of sediment samples included $\mathrm{CaCO}_{3}$ and loss of ignition analysis. The first step was the oven drying of the sediment $(1 \mathrm{~g})$. The second step included the heating of the samples in a muffle furnace at $550{ }^{\circ} \mathrm{C}$, then calculated as the loss of ignition (heating time was four hours, heat retention time four hours). The third step included the re-heating of the samples in the furnace at $950{ }^{\circ} \mathrm{C}$, then calculating the $\mathrm{CaCO}_{3}$ (heating time was four hours, heat retention time two hours) [38].

\subsection{Processing of Cladocera Samples}

The first samples were filtered using a $35-\mu \mathrm{m}$ sieve during the preparation of planktonic samples for the analysis of the contemporary Cladocera community, and then, samples were treated with $96 \%$ Patosolv alcohol (mixture of ethyl-alcohol and isopropanol) to better preserve individual specimens. A few drops of safranin-glycerin (adding a few drops of safranin dye to a small amount of glycerin) were added to simplify identification.

Sediment samples for subfossil Cladocera analysis were prepared according to the standard methodology of Korhola and Raution [39]. One cubic centimeter of sediment was treated with $100 \mathrm{~mL}$ of $10 \% \mathrm{KOH}$ solution (10 g of $\mathrm{KOH}$ pellets dissolved in $100 \mathrm{~mL}$ of deionized water) in a plastic beaker $(150 \mathrm{~mL})$ heated for $30 \mathrm{~min}$ at $70^{\circ} \mathrm{C}$ in a Stuart SWB6D laboratory water bath. Then, the samples were sieved using a 35- $\mu \mathrm{m}$ sieve. The prepared samples were also preserved with $96 \%$ Patosolv alcohol, and a safranin-glycerin solution was also used. Identification of the species was conducted using an Olympus BX53 microscope with an Olympus DP26 fidelity digital camera. In the case of the contemporary and subfossil Cladocera communities, $100 \mu \mathrm{L}$ of sample/slide were used, and at least 200 individuals were counted. The contemporary and subfossil Cladocera communities were identified based on the classification schemes of Frey [40] and Szeroczyńska and Sarmaja-Korjonen [41] and based on Gulyás and Forró [42], respectively. 


\subsection{Data Analysis}

We partitioned the diversity of the oxbow lake for both contemporary and subfossil Cladocera communities using "adespatial" packages [43]. In the analysis, we used the so-called SDR-simplex analysis [44]. This technique was developed to partition gamma diversity into further components. This method evaluates species replacement (RepL), richness differences (RichDiff), and similarity (Sørensen similarity). Species replacement plus richness differences represented the beta-diversity; richness differences plus similarity reflected nestedness; and similarity plus species replacement reflected species richness agreement. To visualize the result, a simplex plot was drawn using $\mathrm{R}$ language [45]. PAST (PAleontological STatistics) software [46] was used to evaluate the Simpson diversity for both contemporary and subfossil Cladocera communities.

Non-metric multidimensional scaling (NMDS) was used to display the similarity of Cladocera communities. The Rogers-Tanimoto index was used to measure the similarity of the species composition, and the Bray-Curtis index was used to measure the dissimilarity of the abundance distribution of communities [47]. NMDS represents the pairwise dissimilarity between objects in a low-dimensional space (usually two-dimensional) preserving the ranks of pair-wise similarities and/or dissimilarities.

\section{Results}

\subsection{Environmental Variables}

The water depth of the oxbow lake surveyed ranged between 0.36 and $6.22 \mathrm{~m}$, the shallower part located mainly in the protected area (Table 1). There were no considerable spatial variabilities in $\mathrm{pH}$ and water transparency. In general, oxbow lakes are characterized by weakly alkaline water with a slight fluctuation in $\mathrm{pH}$ (7.6-8.9), while the water transparency was rather low with a maximum of $0.77 \mathrm{~m}$. High variations in conductivity, chlorophyll-a, and loss of ignition (LOI) were recorded. Conductivity ranged from $398 \mu \mathrm{S} \mathrm{cm}{ }^{-1}$-measured in the protected area (median $424 \mu \mathrm{S} \mathrm{cm}{ }^{-1}$ ) — to $1215 \mu \mathrm{S} \mathrm{cm}^{-1}$ in the recreational area (median $1180 \mu \mathrm{S} \mathrm{cm}^{-1}$ ). The highest concentrations of the living algal biomass (chlorophyll-a) were determined in the protected area, although the highest average was noted in the recreational area. LOI followed the same trend (Table 1). The value of ortho-phosphate in the protected area reached $0.06 \mathrm{mg} \mathrm{L}^{-1}$ (maximum value). This part of the oxbow lake was characterized by the highest submerged coverage.

Table 1. The physical and chemical variables measured in the studied oxbow lake. Abbreviations: $\mathrm{DIN}^{*}=$ dissolved inorganic nitrogen, SS ${ }^{* *}=$ suspended solids, $\mathrm{LOI}{ }^{* * *}=$ loss of ignition.

\begin{tabular}{|c|c|c|c|c|c|c|c|c|c|}
\hline & \multicolumn{3}{|c|}{ Protected Area } & \multicolumn{3}{|c|}{ Biomanipulated Area } & \multicolumn{3}{|c|}{ Recreational Area } \\
\hline & Min. & Max. & Med. & Min. & Max. & Med. & Min. & Max. & Med. \\
\hline Conductivity $\left(\mu \mathrm{S} \mathrm{cm} \mathrm{cm}^{-1}\right)$ & 398 & 788 & 424 & 709 & 1018 & 829 & 1142 & 1215 & 1180 \\
\hline Depth (m) & 0.49 & 4.74 & 0.77 & 0.76 & 3.62 & 1.15 & 0.36 & 6.22 & 1.76 \\
\hline $\mathrm{DIN}^{*}\left(\mathrm{mg} \mathrm{L}^{-1}\right)$ & 0.76 & 3.27 & 1.91 & 0.63 & 1.55 & 1.27 & 0.67 & 1.43 & 0.93 \\
\hline Dissolved oxygen $\left(\mathrm{mg} \mathrm{L}^{-1}\right)$ & 1.27 & 9.84 & 4.36 & 7.1 & 10.7 & 8.09 & 3.62 & 9.25 & 6.84 \\
\hline Open water surface $(\%)$ & 0 & 100 & 60 & 15 & 100 & 100 & 5 & 100 & 50 \\
\hline Ortho-phosphate $\left(\mathrm{mg} \mathrm{L}^{-1}\right)$ & 0 & 0.60 & 0.05 & 0 & 0 & 0 & 0 & 0.29 & 0.01 \\
\hline $\mathrm{pH}$ & 7.6 & 8.6 & 7.9 & 8.3 & 8.7 & 8.5 & 7.8 & 8.9 & 8.7 \\
\hline $\mathrm{SS}^{* *}\left(\mathrm{mg} \mathrm{L}^{-1}\right)$ & 0.6 & 9.6 & 1.8 & 1.8 & 2.9 & 2.3 & 1.8 & 3.1 & 2.7 \\
\hline Transparency (m) & 0.39 & 0.77 & 0.59 & 0.46 & 0.64 & 0.54 & 0.36 & 0.73 & 0.73 \\
\hline $\mathrm{CaCO}_{3}(\%)$ & 1.67 & 10.51 & 7.07 & 2.15 & 16.12 & 6.25 & 2.36 & 6.87 & 5.79 \\
\hline $\mathrm{LOI}^{* * *}(\%)$ & 7.99 & 78.28 & 9.90 & 1.03 & 25.81 & 15.06 & 2.59 & 30.80 & 15.10 \\
\hline Chlorophyll-a $\left(\mathrm{mg} \mathrm{m}^{-3}\right)$ & 2.17 & 22.18 & 7.07 & 7.98 & 11.09 & 7.07 & 5.65 & 13.65 & 13.44 \\
\hline Submerged coverage (\%) & 0 & 91 & 0 & 0 & 5 & 0 & 0 & 5 & 0 \\
\hline
\end{tabular}




\subsection{Contemporary vs. Subfossil Cladocera Communities}

A total of 28 species was found, belonging to four families (Figure S2): Bosminidae, Chydoridae, Daphniidae, Moinidae. The contemporary community was represented by 17 species, while 23 species were identified within subfossil Cladocera communities.

There were 13 species occurring both in the water column and in sediment. Four species were found only in the contemporary community: Moina micrura, Bosmina longispina, Camptocercus rectirostris, and Daphnia longispina, while up to 10 species were noted only in the subfossil community: Pseudochydorus globosus, Pleuroxus uncinatus, Pleuroxus trigonellus, Disparalona rostrata, Alona affinis, Alona costata, Alona rustica, Leydigia leydigi, Paralona pigra, and Unapertura latens. The dominant species in the contemporary samples were Eubosmina coregoni, B. longirostris, and Chydorus sphaericus, while the majority of subfossil remains belonged to the Chydoridae family and were mainly represented by Alona intermedia and C. sphaericus.

The Simpson diversity index was used to demonstrate the relationship between the contemporary and the subfossil community and the differences between each study site. The results are juxtaposed with the number of species (no dimension (ND)) and abundances (ind. $\mathrm{L}^{-1} /$ ind. $\mathrm{cm}^{-3}$ ) of both communities in Figure 2. Differences in diversity, species richness, and heterogeneity for contemporary, and subfossil communities were observed. The differences were also observed between the three parts of the oxbow lake.

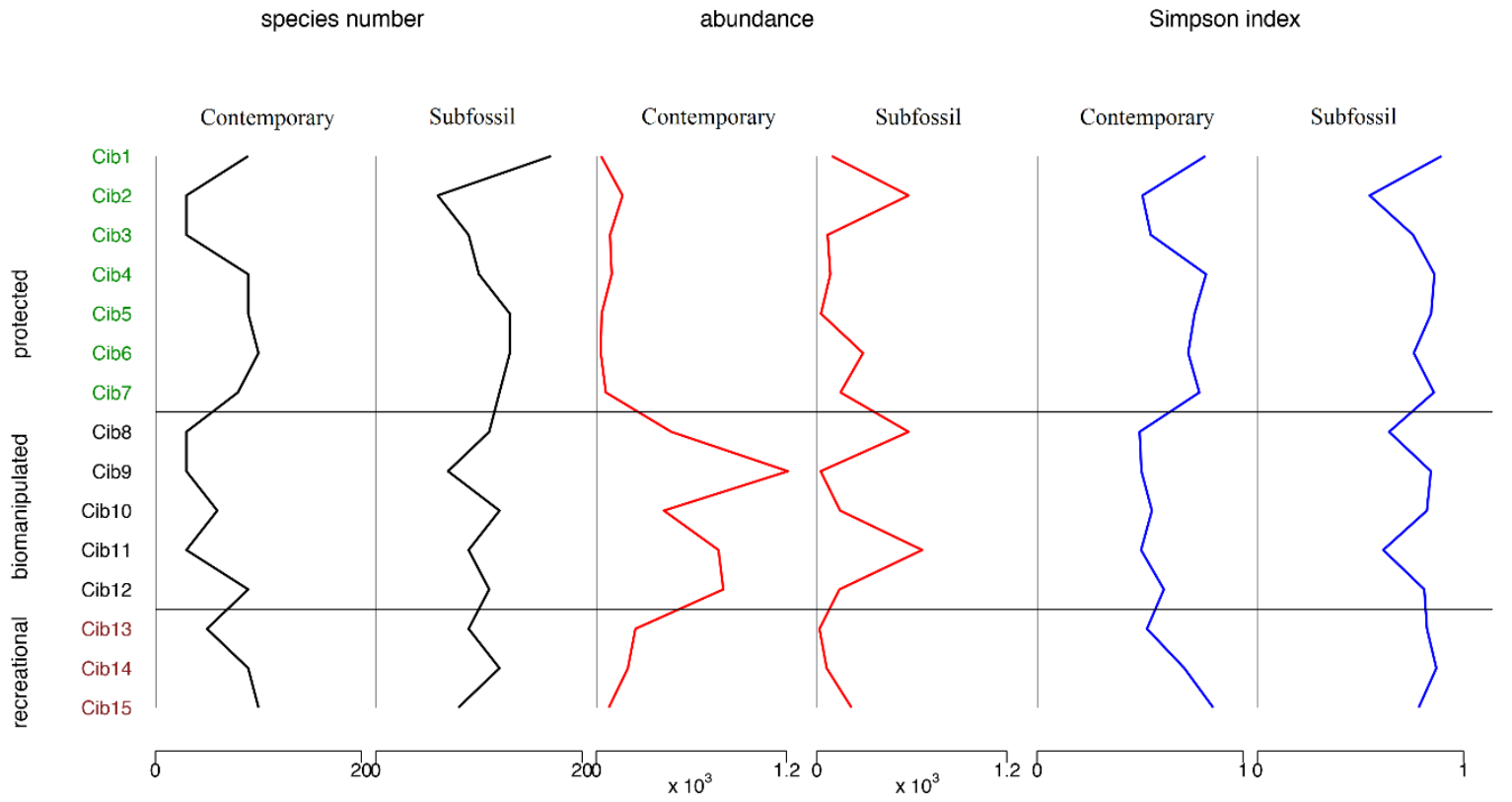

Figure 2. Number of species (ND), abundances (individual $\mathrm{L}^{-1}$ /individual $\mathrm{cm}^{-3}$ ), and Simpson diversity (ND) of contemporary and subfossil Cladocera communities (ND: no dimension).

The number of contemporary Cladocera communities ranged between three and 10 in the protected area, while subfossil communities ranged from 6-17. In the biomanipulated area, the number of species ranged from 3-9 and from 7-12 in the contemporary and subfossil communities, respectively. Similar patterns were recorded in the recreational area where contemporary communities were made up of 5-9 species, while the species number in the subfossil community ranged between 8 and 12 (Figure 2).

Significant differences were also noticeable in abundances in the contemporary Cladocera community between the different utilization forms (protected area: ranging between 30 and 166 ind. $\mathrm{L}^{-1}$; biomanipulated area: ranging between 426 and 1209 ind. $\mathrm{L}^{-1}$; recreational area: ranging between 79 and 247 ind. $\mathrm{L}^{-1}$ ). Dissimilarities were also observed in the frequency of subfossil Cladocera along a stress gradient (protected area: ranging between 27 and 580 ind. $\mathrm{cm}^{-3}$; biomanipulated area: ranging between 25 and 665 ind. $\mathrm{cm}^{-3}$; recreational area: ranging between 17 and 220 ind. $\mathrm{cm}^{-3}$ ). Some 
similarities between contemporary and subfossil communities along the different utilization forms were noticed. For instance, the highest Cladocera abundance was noted in the biomanipulated area. However, the lowest numbers of individuals of contemporary and subfossil Cladocera were observed in the protected area and the recreational area, respectively (Figure 2).

The Simpson diversity indicated that the recreational area (ranging between 0.5329 and 0.8545 ) was a transition between the protected area (ranging between 0.5111 and 0.8198 ) and the biomanipulated area (ranging between 0.4973 and 0.6150 ) in the case of contemporary communities. What is more, according to this index, the values of the subfossil community were higher (protected area: ranging between 0.5438 and 0.8926 ; biomanipulated area: ranging between 0.6100 and 0.8413 ; recreational area: ranging between 0.7821 and 0.8677 ) compared to the contemporary community (Figure 2).

Beta diversity was mostly driven by similarity in both Cladocera communities. Richness differences and replacement were very low in the contemporary and subfossil communities. Beta diversity (sum of richness differences and replacement; contemporary community: 37.2\%) was lower than nestedness (sum of richness differences and similarity; contemporary community: $89.6 \%$ ). This pattern was nearly the same in the case of the subfossil Cladocera communities, since its beta diversity (33.5\%) was lower than its nestedness (81.5\%) (Figure 3).
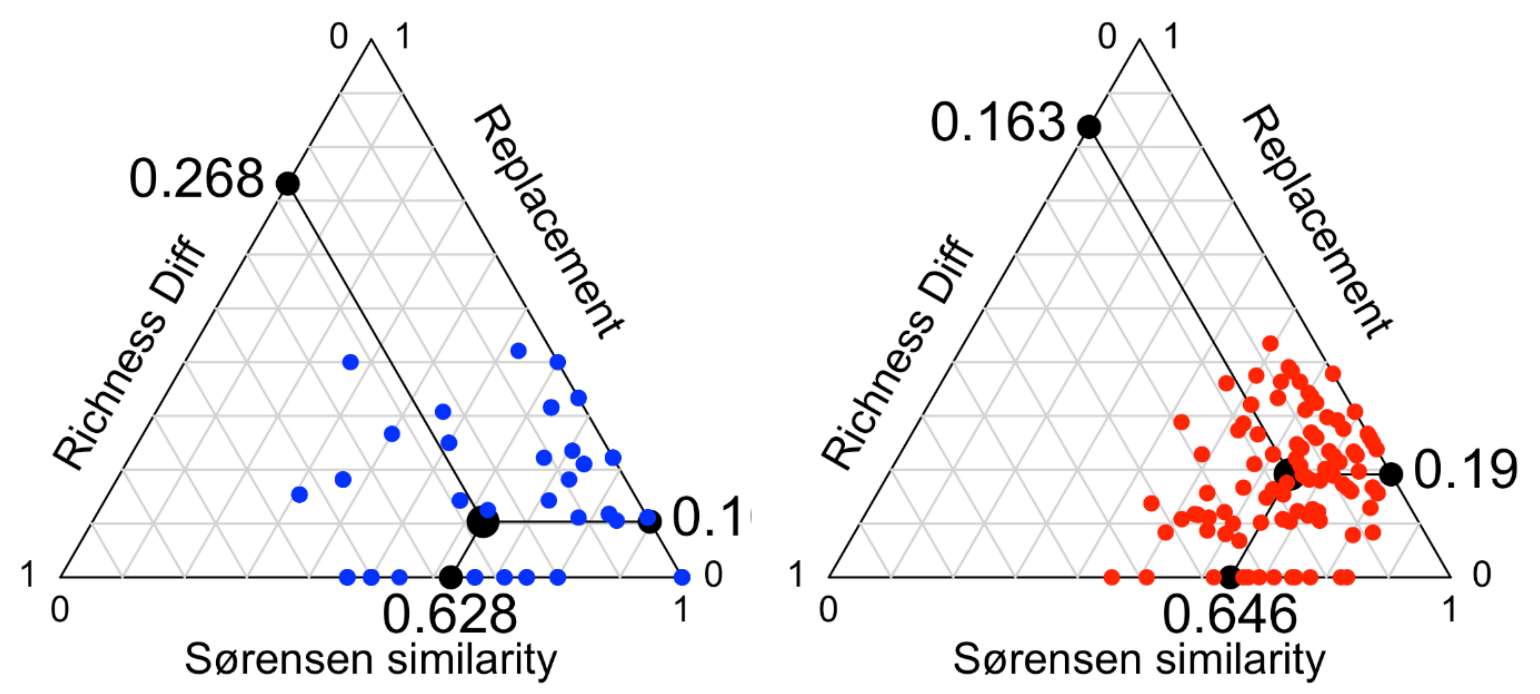

Figure 3. Simplex plots based on similarity, richness differences, and species replacement for all the pairwise comparisons of the Cladocera communities of the 15 sampling sites of the Cibakháza oxbow lake. Notations: $\bullet$, contemporary Cladocera communities; $\bullet$, subfossil Cladocera communities.

The results of the NMDS based on the Rogers-Tanimoto similarity (Figure 4A) showed that the species composition of contemporary Cladocera communities overlapped among the three areas. The protected area, the biomanipulated area, and the recreational area were separated from each other based on species abundances of the contemporary community (Figure 4B). The species abundances of the protected area were separated from the biomanipulated area along the first axis, while the recreational area showed similarity to the protected area (NMDS; Bray-Curtis dissimilarity). The NMDS, based on Rogers-Tanimoto similarity, also showed an overlap among the areas in the case of the species composition of subfossil communities. Nonetheless, the protected area and the recreational area displayed high similarity. These areas were separated from the biomanipulated area along the first axis (Figure 4C). The second axis separated the protected area from the recreational area (Figure 4D), while the biomanipulated area overlapped with the protected area. 

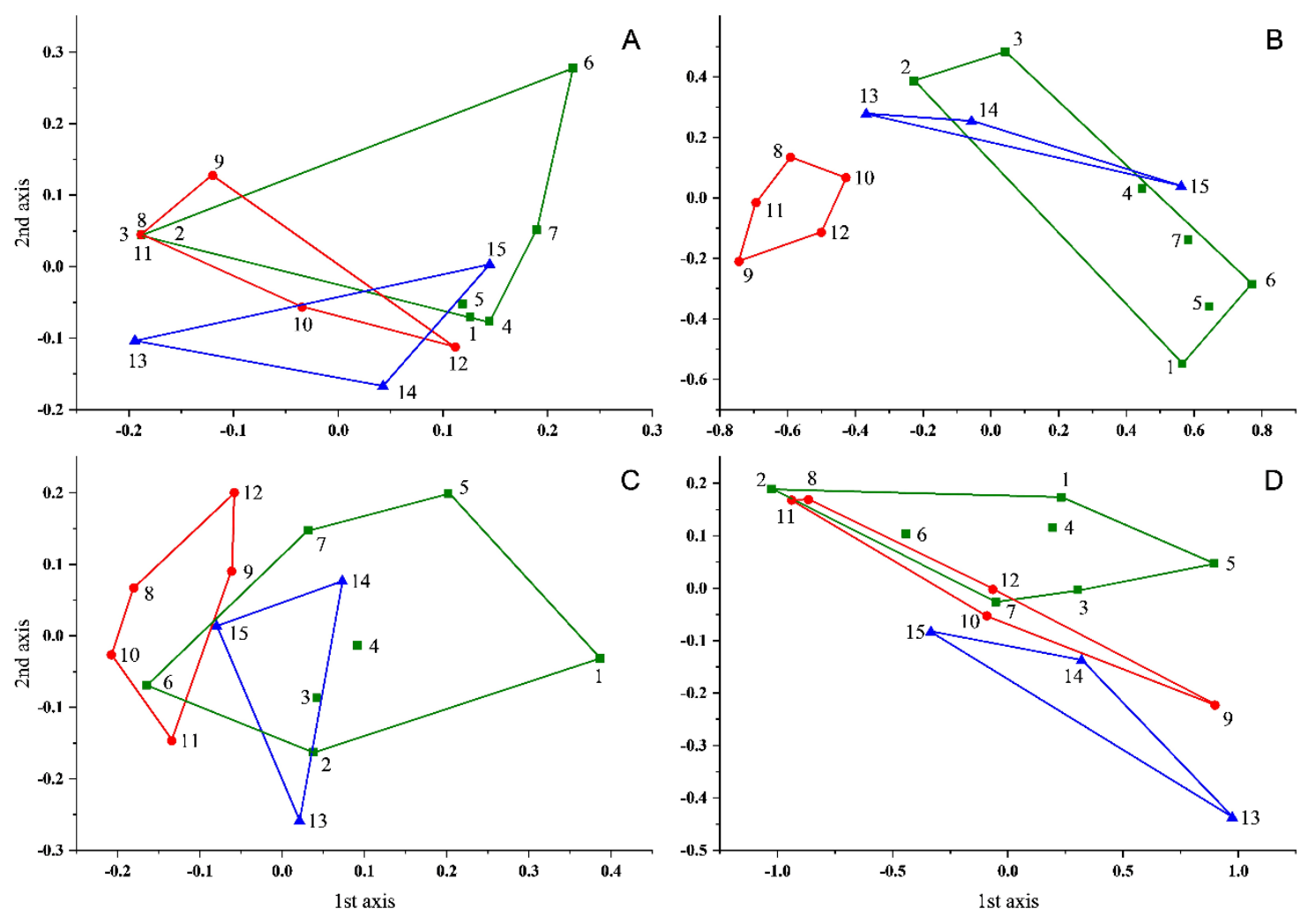

Figure 4. Non-metric multidimensional scaling (NMDS) of the Cladocera communities based on the Rogers-Tanimoto index (binary) and Bray-Curtis index (abundance) of the Cladocera communities. Numbers/symbols represent the samples. 1-7: protected area, 8-12: biomanipulated area, 13-15: recreational area. (A) Contemporary Cladocera communities, Bray-Curtis dissimilarity (stress $=0.3813$ ); (B) contemporary Cladocera communities, Rogers-Tanimoto similarity (stress $=0.2568$ ); (C) subfossil Cladocera communities, Rogers-Tanimoto similarity (stress $=0.2732$ ); (D) subfossil Cladocera communities, Bray-Curtis dissimilarity (stress $=0.1439$ ).

\section{Discussion}

There is an increasing need to resolve the relationship between contemporary and subfossil Cladocera communities and to provide a reliable picture of whether the subfossil community is truly representative of the contemporary community [48-50]. Most of the published subfossil studies on Cladocera communities are specifically limited to examining deep and cold water bodies [51-53]. In contrast, we studied both contemporary and subfossil Cladocera communities in a shallow, temperate water body.

The present research confirmed the earlier findings that the contemporary Cladocera community almost always underestimated the species pool of the waterbody. Estimation of the planktonic and littoral community was regarded as satisfactory, while the number and abundances of the benthic community were underestimated. On the other hand, the study of subfossil communities seems to complement this picture and to provide representative data on benthic taxa and also on the accumulation of planktonic and littoral species. This was confirmed by our finding of 17 species in the contemporary community and 23 species in the subfossil Cladocera communities, which constituted more than $80 \%$ of the total species richness ( 28 species). The good accumulation ability of the sediment was also supported by the fact that mud-living Leydigia leydigi, which lives in association with the bottom, was only recorded from the subfossil community. What is more, concentrating only on the protected area of the oxbow lake could lead to misleading conclusions. For instance, in the protected area, there were 13 species in the contemporary community, while the subfossil community was composed of 20 species. The biomanipulated area was characterized by the presence of nine and 16 
taxa in the contemporary and subfossil Cladocera communities, respectively; while in the recreational area, the contemporary and subfossil community both consisted of 14 species.

Our findings suggest that the decreasing number of species of contemporary cladoceran communities is due to fish predation. It is likely that small-sized juvenile fish can swim through the $5 \times 5 \mathrm{~cm}$ diameter net and can spread into all three areas; thus, they put similar predation pressure on the zooplankton everywhere. However, their survival rate is very low, and the main prey of juvenile fishes is rotifers [32]. The biomanipulated area was influenced by the large common carp stock, whose migration was limited to this area. This increased predation pressure can be detected in the biomanipulated area and was manifested in the decrease of the species number of cladocerans and the prevailing contribution of small-sized Cladocera species (Bosmina, Moina) (Figure S2). Large-sized, easily-visible Cladocera species, especially daphnids, are more vulnerable to fish predators [54], while macroinvertebrates prefer small-sized cladocerans (e.g., bosminids, small daphnids). Fish have a great influence on the size distribution of Cladocera species [55]. A decreasing biomass of fish can increase the zooplankton biomass [22,56,57].

The predation effect on benthic cladocerans has not been explored yet. Only a few studies have dealt with the effect of fish on subfossil cladocerans' remains [58-61]. Jeppesen et al. [58] found significant differences in abundance and crustacean remains in arctic lakes with and without fish and also found the effects of invertebrate predators on benthic cladocerans. Amsinck et al. [59] found that brown trout were a less important factor in shaping the cladoceran communities in Faroese lakes due to their less efficient zoo-planktivory. In spite of scarce results, we can assume that fish predation pressure on benthic species is less important than on planktonic species. In this shallow oxbow lake, we could not demonstrate a significant effect of fish on the subfossil Cladocera community since similarities among cladoceran communities were high in the different areas. Based on our results, this means that contemporary Cladocera only provide information about species richness and their abundances at sampling time, while a subfossil community includes Cladocera communities from a whole year. The results correspond well with those of recent studies $[62,63]$. They all show that the use of sedimentary cladoceran remains provides a more complete assessment of species richness and community structure than does conventional point-sampling in the pelagic zone. This is because the sedimentary samples include benthic communities and integrate spatial and seasonal heterogeneity and year-to-year variations.

Both contemporary and subfossil datasets had a high overall similarity $(63 \%$ and $67 \%)$, i.e., the cladoceran fauna of different sites had a remarkable amount in common, so that beta diversities of contemporary and subfossil cladocerans were low, whereas nestedness was high $(89.6 \%$ and $81.5 \%$, respectively). The result of the SDR-simplex analysis on the contemporary and subfossil Cladocera communities of the oxbow lake showed that there were no significant differences in the patterns of the Cladocera communities. For both communities, the replacement of species between sites was low, and the richness differences in sampling sites were also low. Vad et al. [64] found that the beta-diversity of northern Hungarian ponds was driven by species replacement. Tóth et al. [65] confirmed the importance of species replacement in the partitioning of the beta-diversity of soda pans in Hungary. One possible explanation for our results is the distinct dispersion capabilities of cladoceran species. The different dispersion capabilities of cladoceran species would lead to high species replacement. On a larger geographical scale, cladocerans can substitute each other in ecosystem functioning. In our study, distances between sampling sites were small; therefore, cladoceran heterogeneity can be responsible for the level of the nestedness element of the biodiversity of the oxbow lake. Sites 1, 4, 5, 6, 7, and 15 made the largest contribution to the diversity of the oxbow lake, while B. longirostris, B. coregoni, A. intermedia, C. sphaericus, P. laevis, and C. rectirostris abundances varied the most among sites.

These results correspond to our expectations, but if diversity values are broken down to the three areas, we get a different picture of Cladocera diversity. Considering the Simpson diversity of the contemporary Cladocera communities, it can be stated that the values of the biomanipulated area were lower than those of the protected area. This result can demonstrate the impact of introducing fish 
into this part of the oxbow lake. Brucet et al. [66] examined the effects of various abiotic and biotic factors on zooplankton communities, and they also concluded that predation has the greatest impact on the zooplankton communities. This was also reinforced by the fact that fewer species made up the contemporary Cladocera communities in the biomanipulated area than in the protected area. In contrast, the average species abundance was higher in the biomanipulated area compared to the others. This can be explained by the fact that small-sized species that did not fall prey to predation were able to colonize this area efficiently. With a competitive advantage, they could colonize the area at a higher density, and with their smaller-sized bodies, they could have a higher number of individuals in the pelagic region. Reissing et al. [67] found that in the case of fish introduction, the relative density of small zooplankton species is increased. Based on our results, we can conclude that the recreational area constitutes a transition between the protected and the biomanipulated areas.

The changes in the subfossil Cladocera communities did not display the same pattern as in the contemporary community. The effect of predation on the subfossil Cladocera communities was only slightly detectable, which led us to conclude that such an impact (the introduction of fish) did not cause much transformation in the community in the short term, nor did it cause the kind of transformation that could not be restored after the biomanipulation was discontinued.

This study proved that subfossil Cladocera communities in a shallow Hungarian oxbow lake are characterized by higher diversity, species density, and heterogeneity than the contemporary Cladocera communities. This fact has been proven by several previous studies [52,68]. García-Giron et al. [69] deduced that the subfossil Cladocera community reflects the contemporary community. This finding was also true in the studied oxbow lake, but only for the protected and recreational area. In the biomanipulated area, due to the high predation pressure, the species stock of the sediment did not reflect the contemporary Cladocera community, while it might reflect the pre-biomanipulated conditions.

\section{Conclusions}

The sediment represented the Cladocera community with a larger number of species compared to the contemporary communities in all three utilization forms (protected area, biomanipulated area, and recreational area). Therefore, in order to get a representative picture of the entire Cladocera community of a shallow standing water body (oxbow lake), it is considered necessary to involve both contemporary and subfossil Cladocera communities in the research. Simultaneous implementation and use of both sampling methods (filtering of water and sediment sampling) and simultaneous evaluation of the results provided a more complex picture of the Cladocera community.

In summary, our results suggest that the protected area of an oxbow lake can ensure the recolonization of species and the maintenance of diversity. In the short term, the fish introduction does not cause any irreversible change in the Cladocera community. The original structure of the community would quickly recolonize from the protected area.

These findings suggest that it is necessary to take care of the utilization of a water body during an ecological qualification. The involvement of zooplankton species in the ecological quality assessment of the European Water Framework Directive (EU WFD) has already been promoted by Jeppesen et al. [70]. Our research pointed out that Cladocera communities are especially useful to characterize the state of a standing water body.

Supplementary Materials: The following are available online at http:/www.mdpi.com/2073-4441/11/5/929/ s1: Figure S1: Detailed map of sampling points of Cibakháza oxbow lake with the markings of the three differently-utilized areas, Figure S2: Table of the individual density ratios of the contemporary and subfossil Cladocera communities in the examined areas (green: contemporary community; blue: subfossil community).

Author Contributions: Conceptualization, C.B., I.G. (István Gyulai), and B.T.; methodology, C.B.; software, J.K., B.T., and B.B.-B.; validation, B.T., I.G. (István Grigorszky), M.W., and A.S.N.; formal analysis, B.T., J.K., C.B., and I.G. (István Gyulai); investigation, C.B.; resources, C.B. and I.G.(István Gyulai); data curation, B.T. and J.K.; writing, original draft preparation, C.B. and I.G. (István Gyulai); writing, review and editing, I.G. (István Grigorszky), B.T., A.S.N., and I.G. (István Gyulai); visualization, J.K., B.T.; O.A., and B.B.-B.; supervision, M.W. and O.A. 
Funding: The research was financed by the Higher Education Institutional Excellence Programme (20428-3/2018/FEKUTSTRAT) of the Ministry of Human Capacities in Hungary, within the framework of the 4.thematic program of the University of Debrecen. Research was supported by NKFI KH 126477 project.

Acknowledgments: We are grateful for the data of the fish introduction for the Municipality of Cibakháza.

Conflicts of Interest: The authors declare no conflict of interest.

\section{References}

1. Limburg, K.E.; Waldman, J.R. Dramatic declines in North Atlantic diadromous fishes. BioScience 2009, 59, 955-965. [CrossRef]

2. Strayer, D.L.; Dudgeon, D. Freshwater biodiversity conservation: Recent progress and future challenges. J. N. Am. Benthol. Soc. 2010, 29, 344-358. [CrossRef]

3. Vörösmarty, C.J.; McIntyre, P.B.; Gessner, M.O.; Dudgeon, D.; Prusevich, A.; Green, P.; Glidden, S.; Bunn, S.E.; Sullivan, C.A.; Liermann, C.R.; et al. Global threats to human water security and river biodiversity. Nature 2010, 467, 555-561. [CrossRef] [PubMed]

4. Hoof, R.C.; Peterson, W.T. Copepod biodiversity as an indicator of changes in ocean and climate conditions of the northern California current ecosystem. Limnol. Oceanogr. 2006, 51, 2607-2620. [CrossRef]

5. Shurin, J.B.; Clasen, J.L.; Greig, H.S.; Kratina, P.; Thompson, P.L. Warming shifts top-down and bottom-up control of pond food web structure and function. Philos. Trans. R. Soc. Lond. Biol. Sci. 2012, 367, 3008-3017. [CrossRef] [PubMed]

6. Krause, A.E.; Frank, K.A.; Mason, D.M.; Ulanowicz, R.E.; Taylor, W.W. Compartments revealed in food-web structure. Nature 2003, 426, 282-285. [CrossRef]

7. Sarkar, P.; Das, T. Wetland ecosystem services and its valuation with special reference to India-A review. In Biodiversity and Environmental Conservation; Upadhaya, K., Ed.; Discovery Publishing House Pvt.: New Delhi, India, 2016; pp. 59-76.

8. Varga, K.; Dévai, G.; Tóthmérész, B. Land use history of a floodplain area during the last 200 years in the Upper-Tisza region (Hungary). Reg. Environ. Chang. 2013, 13, 1109-1118. [CrossRef]

9. Carneiro, F.M.; Angelini, R.; Carvalho, A.R.; Bini, L.M. Synchrony among limnological variables in a lotic system (Meia Ponte River, Goiás, Brazil). Acta Limnol. Bras. 2009, 21, 287-292.

10. Hoverman, J.T.; Johnson, P.T.J. Ponds and lakes: A journey through the life aquatic. Nat. Educ. Knowl. 2012, $3,17$.

11. Pringle, C. What is hydrologic connectivity and why is it ecologically important? Hydrol. Process. 2003, 17, 2685-2689. [CrossRef]

12. Stella, J.S.; Pratchett, M.S.; Hutchings, P.A.; Jones, G.P. Coral-associated invertebrates: Diversity, ecological importance and vulnerability to disturbance. In Oceanography and Marine Biology: An Annual Review, 1st ed.; Gibson, R.N., Atkinson, R.J.A., Gordon, J.D.M., Eds.; CRC Press: Boca Raton, FL, USA, 2011; Volume 49, pp. 43-109.

13. Obolewski, K. Macrozoobenthos patterns along environmental gradients and hydrological connectivity of oxbow lakes. Ecol. Eng. 2011, 37, 796-805. [CrossRef]

14. Grabowska, M.; Mazur-Marzec, H. Vertical distribution of cyanobacteria biomass and cyanotoxin production in the polymictic Siemianówka Dam Reservoir (eastern Poland). Arch. Pol. Fish. 2014, 22, 41-51. [CrossRef]

15. Kurek, J.; Korosi, J.B.; Jeziorski, A.; Smol, J.P. Establishing reliable minimum count size for cladoceran subfossils sampled from lake sediments. J. Paleolimnol. 2010, 44, 603-612. [CrossRef]

16. Chaparro, G.; Kandus, P.; O'Farrell, I. Effect of spatial heterogeneity on zooplankton diversity: A multi-scale habitat approximation in a floodplain lake. River Res. Appl. 2013, 31, 85-97. [CrossRef]

17. Obolewski, K.; Glińska-Lewczuk, K.; Jarząb, N.; Burandt, P.; Kobus, S.; Kujawa, R.; Okruszko, T.; Grabowska, M.; Lew, S.; Goździejewska, A.; et al. Benthic invertebrates in floodplain lakes of a Polish river: Structure and biodiversity analyses in relation to hydrological conditions. Pol. J. Environ. Stud. 2014, 23, 1679-1689.

18. da Silva, M.T.; Pereira, J.O.; Vieira, L.J.S.; Petry, A.C. Hydrological seasonality of the river affecting fish community structure of oxbow lakes: A limnological approach on the Amapá Lake, southwestern Amazon. Limnologica 2013, 43, 79-90. [CrossRef] 
19. Hunt, R.J.; Matveev, V.F. The effects of nutrients and zooplankton community structure on phytoplankton growth in a subtropical Australian reservoir: An enclosure study. Limnologica 2005, 35, 90-101. [CrossRef]

20. O’Brien, W.J.; de Noyelles, F., Jr. Relationship between nutrient concentration, phytoplankton density, and zooplankton density in nutrient enriched experimental ponds. Hydrobiologia 1974, 44, 105-125. [CrossRef]

21. Tibúrcio, V.G.; Arreieira, R.L.; Schwind, L.T.F.; Bonecker, C.C.; Lansac-Tôha, F.A. Effects of nutrients increase on the copepod community of a reservoir using cages. Acta Limnol. Bras. 2015, 27, 265-274. [CrossRef]

22. Christoffersen, K.; Riemann, B.; Klysner, A.; Søndergaard, M. Potential role of fish predation and natural populations of zooplankton in structuring a plankton community in eutrophic lake water. Limnol. Oceanogr. 1993, 38, 561-573. [CrossRef]

23. Amundsen, P.-A.; Lafferty, K.D.; Knudsen, R.; Primicerio, R.; Kristofferesen, R.; Klemetsen, A.; Kuris, A.M. New parasites and predators follow the introduction of two fish species to a subarctic lake: Implications for food-web structure and functioning. Oecologia 2013, 171, 993-1002. [CrossRef] [PubMed]

24. Iglesias, C.; Mazzeo, N.; Meerhoff, M.; Lacerot, G.; Clemente, J.M.; Scasso, F.; Kruk, C.; Goyenola, G.; García-Alonso, J.; Amsinck, S.L.; et al. High predation is of key importance for dominance of small-bodied zooplankton in warm shallow lakes: Evidence from lakes, fish exclosures and surface sediments. Hydrobiologia 2011, 667, 133-147. [CrossRef]

25. Persson, L.; Byström, P.; Wahlström, E.; Westman, E. Trophic dynamics in a whole lake experiment: Size-structured interactions and recruitment variation. Oikos 2004, 106, 263-274. [CrossRef]

26. Haberman, J. Dominant zooplankton species in Lake Peipsi. Estonian J. Ecol. 2000, 49, 34-51.

27. Mehner, T.; Keeling, C.; Emmrich, M.; Holmgren, K.; Argillier, C.; Volta, P.; Winfield, I.J.; Brucet, S. Effects of fish predation on density and size spectra of prey fish communities in lakes. Can. J. Fish. Aquat. Sci. 2016, 73, 506-518. [CrossRef]

28. Gliwicz, Z.M. Predation or food limitation: An ultimate reason for extinction of planktonic cladoceran species. Arch. Hydrobiol. Beih. Ergeb. Limnol. 1985, 21, 419-430.

29. Jeppesen, E.; Jensen, J.P.; Søndergaard, M.; Lauridsen, T.; Landkildehus, F. Trophic structure, species richness and biodiversity in Danish lakes: Changes along a phosphorus gradient. Freshw. Biol. 2010, 45, 201-218. [CrossRef]

30. Brooks, J.L.; Dodson, S.I. Predation, body size, and composition of plankton. Science 1965, 150, 28-35. [CrossRef] [PubMed]

31. Gliwicz, Z.M. Between hazards of starvation and risk of predation: The ecology of offshore animals. In Excellence in Ecology; Kinne, O., Ed.; International Ecology Institute: Oldendorf/Luhe, Germany, 2003; Volume 12, pp. 1-379.

32. Boltizár, O.; Müller, T.; Csenki, Z.; Bakos, K.; Staszny, Á.; Hegyi, Á.; Kucska, B.; Kucharczyk, D.; Horváth, L. Predatory effect of Copepods on the larvae of some freshwater fish. Fundam. Appl. Limnol. 2017, 190, 349-356. [CrossRef]

33. Frimpong, E.A.; Lochmann, S.E. Mortality of fish larvae exposed to varying concentrations of cyclopoid copepods. N. Am. J. Aquac. 2005, 67, 66-71. [CrossRef]

34. Letcher, B.H.; Rice, J.A.; Crowder, L.B.; Rose, K.A. Variability in survival of larval fish: Disentangling components with a generalized individual-based model. Can. J. Fish. Aquat. Sci. 1996, 53, 787-801. [CrossRef]

35. Spectiár, A. A Balaton halfaunája: A halállomány összetétele, az egyes halfajok életkörülményei és a halállomány korszerú hasznosításának feltételrendszere. Acta Biol. Debr. Oecol. Hung. 2010, 23, 7-185.

36. Schindler, D.W. Two useful devices for vertical plankton and water sampling. J. Fish. Res. Board Can. 1969, 26, 1948-1955. [CrossRef]

37. Glew, J.R. Miniature gravity corer for recovering short sediment cores. J. Paleolimnol. 1991, 5, $285-287$. [CrossRef]

38. Dean, W. Determination of carbonate and organic matter in calcareous sediments and sedimentary rocks by loss on ignition: Comparison with other methods. J. Sediment. Res. 1974, 44, 242-248. [CrossRef]

39. Korhola, A.; Rautio, M. Cladocera and other branchiopod crustaceans. In Tracking Environmental Change Using Lake Sediments: Biological Techniques and Indicators; Smol, J.P., Birks, H.J.B., Last, W.M., Eds.; Kluwer Academic Publisher: Dordrecht, The Netherlands, 2001; Volume 2, pp. 1-38.

40. Frey, D.G. The taxonomy and biogeography of the Cladocera. Hydrobiologia 1987, 145, 5-17. [CrossRef] 
41. Szeroczyńska, K.; Sarmaja-Korjonen, K. Atlas of Subfossil Cladocera from Central and Northern Europe; Friends of the Lower Vistula Society: Świecie, Poland, 2007; pp. 1-84.

42. Gulyás, P.; Forró, L. Az Ágascsápú Rákok (Cladocera) Kishatározója, 2nd ed.; Környezetgazdálkodási Intézet: Budapest, Hungary, 1999; pp. 1-237.

43. Dray, S.; Bauman, D.; Blanchet, G.; Borcard, D.; Clappe, S.; Guenard, G.; Jombart, T.; Larocque, G.; Legendre, P.; Madi, N.; et al. Adespatial: Multivariate Multiscale Spatial Analysis. 2018. Available online: http://CRAN.R-project.org/package=adespatial (accessed on 18 February 2019).

44. Podani, J.; Schmera, D. A new conceptual and methodological framework for exploring and explaining pattern in presence-absence data. Oikos 2011, 120, 1625-1638. [CrossRef]

45. R Core Team. R: A Language and Environment for Statistical Computing; R Foundation for Statistical Computing: Vienna, Austria, 2018; Available online: http://www.R-project.org/ (accessed on 3 March 2018).

46. Hammer, Ø.; Harper, D.A.T.; Paul, D.R. Past: Paleontological statistics software package for education and data analysis. Palaeontol. Electron. 2001, 4, 1-9.

47. Legendre, P.; Legendre, L. Numerical Ecology (Developments in Environmental Modelling), 2nd ed.; Elsevier Science BV.: Amsterdam, The Netherlands, 1998; pp. 1-853.

48. Davidson, T.A.; Sayer, C.D.; Perrow, M.R.; Bramm, M.; Jeppesen, E. Are the controls of species composition similar for contemporary and sub-fossil cladoceran assemblages? A study of 39 shallow lakes of contrasting trophic status. J. Paleolimnol. 2007, 38, 117-134. [CrossRef]

49. Kattel, G.R.; Battarbee, R.W.; Mackay, A.; Birks, H.J.B. Are cladoceran fossils in lake sediment samples a biased reflection of the communities from which they are derived? J. Paleolimnol. 2007, 38, 157-181. [CrossRef]

50. Davidson, T.A.; Amsinck, S.L.; Bennike, O.; Christoffersen, K.S.; Landkildehus, F.; Lauridsen, T.L.; Jeppesen, E. Inferring a single variable from an assemblage with multiple controls: Getting into deep water with cladoceran lake-depth transfer functions. Hydrobiologia 2011, 676, 129-142. [CrossRef]

51. Korhola, A.; Tikkanen, M.; Weckström, J. Quantification of Holocene lake-level changes in Finnish Lapland using a cladocera-Lake depth transfer model. J. Paleolimnol. 2005, 34, 175-190. [CrossRef]

52. Szeroczyńska, K.; Zawisza, E. Subfossil faunal and floral remains (Cladocera, Pediastrum) in two northern Lobelia lakes in Finland. Knowl. Manag. Aquat. Ecosyst. 2011, 402, 9-23. [CrossRef]

53. Tolotti, M.; Milan, M.; Szeroczyńska, K. Subfossil Cladocera as a powerful tool for paleoecological reconstruction. Adv. Oceanogr. Limnol. 2016, 7, 125-130. [CrossRef]

54. Gliwicz, Z.M. Food thresholds and body size in cladocerans. Nature 1990, 343, 638-640. [CrossRef]

55. Boersma, M.; van Densen, W.L.T.; Vijverberg, J. The effect of predation by smelt (Osmerus eperlanus) on Daphnia hyalina in a shallow eutrophic lake. Verh. Int. Ver. Limnol. 1991, 24, 2438-2442. [CrossRef]

56. Sarvala, J.; Helminen, H.; Saarikari, V.; Salonen, S.; Vuorio, K. Relations between planktivorous fish abundance, zooplankton and phytoplankton in three lakes of differing productivity. In Eutrophication in Planktonic Ecosystems: Food Web Dynamics and Elemental Cycling. Developments in Hydrobiology; Tamminen, T., Kuosa, H., Eds.; Springer: Dordrecht, The Netherlands, 1998; Volume 127, pp. 81-95. [CrossRef]

57. Korponai, J.; Mátyás, K.; Paulovits, G.; Tátrai, I.; Kovács, N. The effect of different fish communities on the cladocerans plankton assemblages of the Kis-Balaton Reservoir, Hungary. In Cladocera: The Biology of Model Organisms. Developments in Hydrobiology; Branceli, A., De Meester, L., Spaak, P., Eds.; Springer: Dordrecht, The Netherlands, 1997; Volume 126, pp. 211-221. [CrossRef]

58. Jeppesen, E.; Christoffersen, K.; Landkildehus, F.; Lauridsen, T.; Amsinck, S.L.; Riget, F.; Søndergaard, M. Fish and crustaceans in northeast Greenland lakes with special emphasis on interactions between Arctic charr (Salvelinus alpinus), Lepidurus arcticus and benthic chydorids. Hydrobiologia 2001, 442, 329-337. [CrossRef]

59. Jeppesen, E.; Jensen, J.P.; Amsinck, S.L.; Landkildehus, F.; Lauridsen, T.; Mitchell, S.F. Reconstruction the historical changes in Daphnia mean size and planktivorous fish abundance in lakes from the size of Daphnia ephippia in the sediment. J. Paleolimnol. 2002, 27, 133-143. [CrossRef]

60. Jeppesen, E.; Jensen, J.P.; Lauridsen, T.L.; Amsinck, S.L.; Christoffersen, K.; Søndergaard, M.; Mitchell, S.F. Sub-fossils of cladocerans in the surface sediment of 135 lakes as proxies for community structure of zooplankton, fish abundance and lake temperature. Hydrobiologia 2003, 491, 321-330. [CrossRef] 
61. Amsinck, S.L.; Strzelczak, A.; Bjerring, R.; Landkildehus, F.; Lauridsen, T.L.; Christoffersen, K.; Jeppesen, E. Lake depth rather than fish planktivory determines cladoceran community structure in Faroese lakes-Evidence from contemporary data and sediments. Freshw. Biol. 2006, 51, 2124-2142. [CrossRef]

62. Brendonck, L.; De Meester, L. Egg banks in freshwater zooplankton: Evolutionary and ecological archives in the sediment. Hydrobiologia 2003, 491, 65-84. [CrossRef]

63. Vandekerkhove, J.; Declerck, S.; Brendonck, L.; Conde-Porcuna, J.M.; Jeppesen, E.; Johansson, L.S.; De Meester, L. Uncovering hidden species: Hatching diapausing eggs for the analysis of cladoceran species richness. Limnol. Oceanogr. 2005, 3, 399-407. [CrossRef]

64. Vad, C.F.; Horváth, Z.; Kiss, K.T.; Ács, É. Microcrustacean (Cladocera, Copepoda) communities in artificial lakes in the region of the North Hungarian mountains, with special reference to the adventive species. Acta Zool. Acad. Sci. Hung. 2012, 58, 47-61.

65. Tóth, A.; Horváth, Z.; Vad, C.F.; Zsuga, K.; Nagy, S.A.; Boros, E. Zooplankton of the European soda pans: Fauna and conservation of a unique habitat type. Int. Rev. Hydrobiol. 2014, 99, 255-276. [CrossRef]

66. Brucet, S.; Boix, D.; Quintana, X.D.; Jensen, E.; Nathansen, L.W.; Trochine, C.; Meerhoff, M.; Gascón, S.; Jeppesen, E. Factors influencing zooplankton size structure at contrasting temperatures in coastal shallow lakes: Implications for effects of climate change. Limnol. Oceanogr. 2010, 55, 1697-1711. [CrossRef]

67. Reissing, M.; Trochine, C.; Queimaliños, C.; Balseiro, E.; Modenutti, B. Impact of fish introduction on planktonic food webs in lakes of the Patagonian Plateau. Biol. Conserv. 2006, 132, 437-447. [CrossRef]

68. Çakiroğlu, A.I.; Tavşanoğlu, Ü.N.; Levi, E.E.; Davidson, T.A.; Bucak, T.; Özen, A.; Akyildiz, G.K.; Jeppesen, E.; Beklioğlu, M. Relatedness between contemporary and subfossil cladoceran assemblages in Turkish lakes. J. Paleolimnol. 2014, 52, 367-383. [CrossRef]

69. García-Girón, J.; Fernández-Aláez, C.; Fernández-Aláez, M.; Luis, B. Subfossil Cladocera from surface sediment reflect contemporary assemblages and their environmental controls in Iberian flatland ponds. Ecol. Indic. 2018, 87, 33-42. [CrossRef]

70. Jeppesen, E.; Nõges, P.; Davidson, T.A.; Haberman, J.; Nõges, T.; Blank, K.; Lauridsen, T.L.; Søndergaard, M.; Sayer, C.; Laugaste, C.; et al. Zooplankton as indicators in lakes: A scientific-based plea for including zooplankton in the ecological quality assessment of lakes according to the European Water Framework Directive (WFD). Hydrobiologia 2011, 676, 279-297. [CrossRef] 